\title{
Analisis Strategi Komunikasi Pemasaran Shopee dalam Persaingan E-Commerce di Indonesia
}

\author{
Sharen Kangean, Farid Rusdi \\ sharen.915160013@stu.untar.ac.id,faridr@fikom.untar.ac.id \\ Fakultas Ilmu Komunikasi Universitas Tarumanagara
}

\begin{abstract}
The development of internet technology is increasing. With the rapid internet technology, Indonesian people's spending patterns are shifting. Shopping activities that used to only be through stores directly, but now can using internet technology known as online shopping. Online Shopping can be accessed through digital applications known as e-commerce applications. One of the well-known e-commerce sites in Indonesia is Shopee. In this case, the problem in this research is to study about marketing communication strategies and the implementation of Shopee marketing communication. The theoretical used in this research is marketing communication, and SOSTAC analysis. The method suggested in this research is qualitative approach. The resources interviewees in this research are Shopee's Business Development and Shopee's users with different needs. The results of this research indicate the marketing strategy used are push strategies in the form of advertisements and events with pull strategies in the form of sales promotions.
\end{abstract}

Keywords: marketing communication, Shopee, SOSTAC.

\begin{abstract}
Abstrak
Perkembangan teknologi internet semakin hari semakin berkembang pesat. Adanya teknologi internet yang pesat, pola belanja masyarakat Indonesia bergeser. Kegiatan belanja yang dulu hanya dapat dilakukan melalui toko secara langsung, sekarang dilakukan dengan teknologi internet dikenal dengan istilah online shopping. Belanja secara daring (online) dapat diakses melalui aplikasi digital yang dikenal dengan istilah aplikasi $e$-commerce. Salah satu e-commerce yang ternama di Indonesia adalah Shopee. Dalam hal ini, terdapat perumusan masalah dalam penelitian ini adalah untuk mengetahui strategi komunikasi pemasaran serta pelaksanaan komunikasi pemasaran Shopee. Landasan teori yang digunakan dalam penelitian ini adalah komunikasi pemasaran, dan analisis SOSTAC. Metode pendekatan dalam penelitian ini adalah pendekatan kualitatif. Narasumber dalam penelitian ini merupakan Business Development Shopee dan pengguna Shopee dengan kebutuhan yang berbeda. Hasil penelitian ini menunjukkan bahwa strategi komunikasi pemasaran yang digunakan adalah adalah push strategy dalam bentuk iklan dan event serta pull strategy berupa promosi penjualan.
\end{abstract}

Kata Kunci: Komunikasi Pemasaran, Shopee, SOSTAC.

\section{Pendahuluan}

Dalam kehidupan sehari-hari, setiap manusia memerlukan kebutuhan untuk keberlangsungan hidup. Di zaman modern, yang awalnya kebutuhan primer semula manusia hanya sandang, pangan, dan papan kini juga memiliki kebutuhan lain yang dibeli untuk memenuhi keinginan manusia. Untuk mendapatkan barang dan jasa, 
manusia harus melakukan kegiatan belanja. Belanja adalah kegiatan berupa transaksi jual beli untuk mendapatkan barang dan jasa. Salah satu tempat kegiatan belanja yang konvensional adalah dengan datang ke toko barang dan jasa.

Adanya teknologi internet, pola belanja masyarakat bergeser. Kegiatan belanja dengan menggunakan teknologi internet dikenal dengan istilah online shopping. Belanja secara daring (online) dapat diakses melalui aplikasi digital yang dikenal dengan istilah aplikasi e-commerce. Efisien dan harga yang kompetitif membuat e-commerce tumbuh subur di Indonesia (CNN Indonesia, 11 Agustus 2017).

Perdagangan eletronik atau Electronic commerce (e-commerce) adalah suatu istilah yang digunakan untuk kegiatan belanja yang diakses melalui jaringan internet berbasis online. Aplikasi e-commerce digunakan oleh masyarakat sebagai wadah belanja baru yang berbasis online sehingga pembeli tidak perlu datang ke toko, hanya tinggal "klik" pada aplikasi e-commerce (Mujiyana \& Elissa, 2013). Beberapa aplikasi e-commerce yang paling banyak digunakan di Indonesia adalah Shopee, Tokopedia, Bukalapak, Lazada, Blibli, Elevania dan aplikasi e-commerce lainnya.

Shopee merupakan perusahaan e-commerce yang berasal dari Singapura dibawah naungan perusahaan Garena. Shopee mulai masuk ke Indonesia sejak tahun 2015. Shopee menjadi e-commerce dengan jumlah transaksi terbanyak kedua setelah Tokopedia. Pada saat kuartal pertama (per bulan Januari sampai Maret) 2019, jumlah transaksi Shopee di Indonesia menyentuh angka 20,1 triliun rupiah. Secara tidak langsung, Indonesia menyumbang duapertiga dari total transaksi Shopee secara keseluruhan di Asia Tenggara yang sebesar 3,5 miliar US dolar atau setara dengan 50,4 triliun rupiah. Hal ini menjadikan Shopee menduduki urutan kedua e-commerce Indonesia setelah Tokopedia (CNN Indonesia, 31 Mei 2019).

Shopee merupakan salah satu aplikasi e-commerce yang melayani transaksi jual beli secara online yang berisikan berbagai macam barang dan jasa. Produk yang dijual mulai dari pakaian, mainan, perangkat seluler, dan segala jenis barang lainnya. selain itu, Shopee juga dapat digunakan untuk pembelian pulsa, token listrik, voucher makan, dan lain-lain.

Shopee masuk ke Indonesia pada tanggal 1 Desember 2015. Berdasarkan data dari CNN Indonesia, hingga Melansir data dari Katadata.co.id, laporan keuangan Shopee di kuartal kedua (bulan April sampai Juni) 2019 Shopee menembus jumlah transaksi dengan rata rata 1,2 juta transaksi yang dilakukan per hari (Katadata.co.id, 27 November 2019).

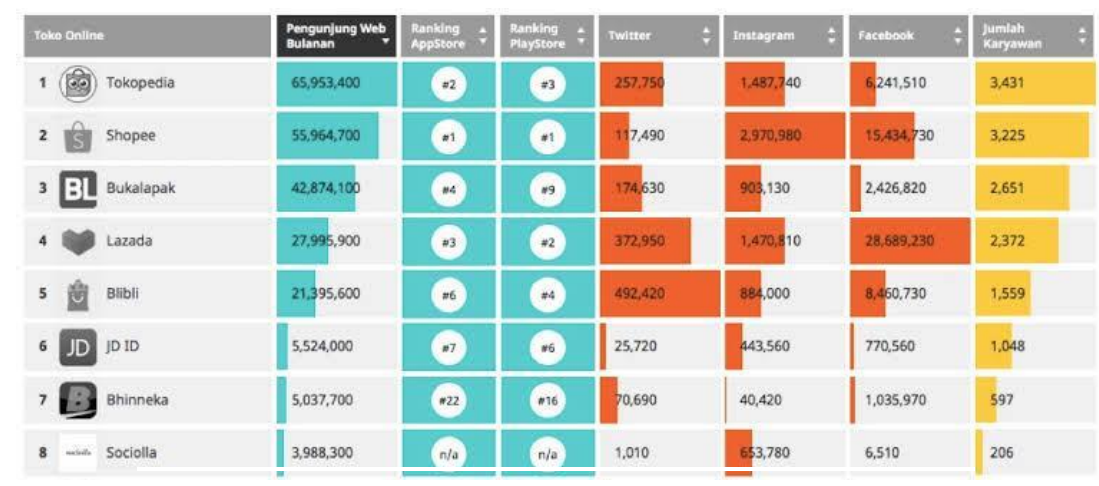

Untuk dapat bertahan di tengah persaingan, Shopee memerlukan strategi komunikasi pemasaran yang lebih gencar agar dapat menarik minat pembeli. Komunikasi pemasaran atau marketing communication merupakan suatu konsep 
yang menggabungkan dua ilmu, yakni ilmu komunikasi dan ilmu pemasaran. Komunikasi pemasaran merupakan kegiatan komunikasi yang bertujuan untuk menawarkan, memberitahu, menyampaikan pesan akan nilai-nilai berupa produk atau jasa perusahaan sehingga dapat diketahui oleh konsumen (Priansa, 2017:94).

Konsep komunikasi pemasaran terpadu atau integrated marketing communications menurut Schultz dalam Priansa (2017:100) merupakan sebuah strategi bisnis dengan membuat rencana, pengimplementasian dan mengevaluasi dari program komunikasi pemasaran yang dibuat.

Menurut Boone and Kurtz dalam Priansa (2017) komunikasi pemasaran terpadu merupakan rancangan dari bauran pemasaran yang terdiri dari periklanan, penjualan langsung, penjualan personal, promosi penjualan, dan kegiatan publikasi untuk menyampaikan pesan akan nilai-nilai perusahaan kepada konsumen.

Dalam komunikasi pemasaran terpadu terdapat bauran komunikasi. Bauran komunikasi pemasaran merupakan alat-alat yang digunakan untuk menyampaikan pesan promosi kepada target pasar. Enam bauran komunikasi pemasaran menurut Suwatno (2017:85-98), yaitu periklanan, pemasaran langsung, promosi penjualan, penjualan personal, pemasaran interaktif, dan public relations.

Dalam penelitian ini, penulis menggunakan analisa Situation Analysis, Objectivities, Strategy, Tactic, Action and Control (SOSTAC).

Melalui penjelasan yang dijabarkan, strategi komunikasi pemasaran penting dilakukan sekarang ini agar dapat tetap bertahan dalam persaingan khususnya $e$ commerce seperti Shopee. Peneliti memilih strategi komunikasi pemasaran untuk dapat menganalisis komunikasi pemasaran apa yang dipakai oleh Shopee.

Penelitian ini dilakukan oleh penulis karena Shopee merupakan e-commerce yang baru masuk ke Indonesia dan sudah bisa menduduki posisi kedua e-commerce terbesar di Indonesia setelah Tokopedia.

Bedasarkan latar belakang, maka penulis mendapatkan rumusan masalah sebagai berikut:

a. Bagaimana strategi komunikasi pemasaran Shopee dalam persaingan dengan $e$ commerce lain di Indonesia?

b. Bagaimana pelaksanaan strategi komunikasi pemasaran Shopee dalam persaingan e-commerce di Indonesia?

Penelitian ini bertujuan untuk untuk mengetahui strategi komunikasi pemasaran serta mengetahui pelaksanaan strategi komunikasi pemasaran Shopee.

\section{Metode Penelitian}

Penelitian ini menggunakan metode kualitatif. Penelitian kualitatif adalah metode penelitian yang digunakan untuk meneliti suatu peristiwa yang mana penulis membangun pandangan melalui penjelasan deskriptif. Teknik pengumpulan data yang dilakukan adalah denganmencocokan data dengan berbagai teori dan sumber (Sugiyono, 2016:1).

Pengumpulan data dilakukan dengan cara wawancara, observasi dan dokumentasi. Narasumber dalam penelitian ini adalah Business Development Shopee Indonesia, Yoga Pratama dan enam orang pengguna Shopee di Jakarta dengan latar belakang mahasiswa, dan karyawan.

Subjek dalam penelitian ini adalah perusahaan Shopee yang merupakan perusahaan e-commerce. Objek penelitian ini adalah strategi komunikasi pemasaran yang dilakukan oleh Shopee. Data penelitian yang telah dikumpulkan, kemudian 
akan dianalisis menggunakan analisis Situation Analysis, Objectivities, Strategy, Tactic, Action and Control (SOSTAC).

Menurut Paul Smith dalam Suherman (2016), SOSTAC merupakan langkah yang sistematis dalam menyusun sebuah strategi komunikasi pemasaran dengan menganalisis kondisi internal dan eksternal perusahaan. Penulis memilih penjabaran melalui SOSTAC karena penjabaran lebih detil dan terinci dalam menyusun strategi komunikasi pemasaran.

\section{Hasil Penemuan dan Diskusi}

Penulis menguraikan berbagai temuan dan analisis strategi komunikasi pemasaran yang digunakan oleh Shopee. Dalam melakukan analisis penelitian, penulis menggunakan analisis dengan teori SOSTAC, yaitu Situation analysis, Objectivities, Strategy, Tactics, Action dan Control.

\section{Situation Analysis}

Keunggulan Shopee dibanding e-commerce lainnya adalah selalu mengadakan fitur dan promo yang dimiliki Shopee pertama kali seperti gratis ongkos kirim (ongkir) dan fitur yang terdapat pada aplikasi Shopee seperti Shopee games. Shopee memiliki kelemahan berupa penanganan konsumen. Konsumen sering memiliki kendala dalam melakukan transaksi dengan penjual seperti kendala barang yang tidak sampai di pengguna dan pembatalan sepihak. Kelemahan bisa harus dapat diatasi agar pengguna tetap menggunakan Shopee sebagai tempat tujuan berbelanja.

Peluang Shopee dalam menghadapi persaingan aplikasi e-commerce lainnya adalah selalu membuat program dan fitur-fitur unik yang pertama kali ada dibanding e-commerce lain. Kondisi yang dapat mengancam Shopee adalah konsistensi dari inovasi yang dibuat. Temuan seperti gratis ongkir dan pemakaian brand ambassador sudah banyak e-commerce yang mengikuti cara Shopee. Seperti contoh e-commerce seperti Bukalapak dan Tokopedia yang sudah menerapkan gratis ongkir. Tokopedia dengan penggunaaan brand ambassador, grup boyband korea, Bangtan Boys (BTS).

\section{Objectivities}

Shopee memiliki visi dan misi. Visi Shopee adalah Menjadi mobile marketplace nomor 1 di Asia Tenggara. Misi Shopee adalah percaya pada kekuatan transformatif teknologi dan ingin mengubah dunia menjadi lebih baik dengan menyediakan platform untuk menghubungkan pembeli dan penjual dalam satu komunitas (Sumber dari https://careers.shopee.co.id/about/ diakses 24 November 2019 pada pukul 13:59 WIB).

Untuk mewujudkan visi dan misi, Shopee menetapkan tujuan untuk mencapai visi dan misi. Shopee berusaha memberikan pelayanan yang terbaik seperti layanan konsumen untuk menanggapi keluhan konsumen 24 jam, memberikan fitur yang menarik dan mudah digunakan, memberikan promosi seperti gratis ongkir dan memasarkan Shopee melalui bauran komunikasi pemasaran seperti iklan, event, promosi, dan lain-lain.

Fitur ulasan dari penjual juga menjadi salah satu daya tarik untuk pelapak dapat menggunakan Shopee. Penulis menemukan bahwa fitur ulasan dari penjual dapat dijadikan sebagai komunikasi dua arah antara penjual dengan pembeli. Sehingga pada saat ingin membeli, rating toko tidak terkena imbas akibat rating 
rendah yang diberikan oleh pembeli dan calon pembeli berikutnya dapat melihat ulasan dari dua belah pihak.

Shopee juga mengadakan perluasan merek ke berbagai bentuk seperti Shopee Mall yang merupakan online store dari sebuah merek resmi. Terdapat juga ShopeePay yang merupakan alat pembayaran digital yang diakses melalui aplikasi Shopee.

\section{Strategy}

Shopee menggunakan strategi tarik dan dorong (push and pull strategy). Push strategy untuk memperkenalkan dan mempromosikan program yang dibuat Shopee kepada calon pengguna. Program biasa dibuat dalam bentuk acara, campaign atau promosi penjualan. Strategi yang digunakan untuk mempromosikan program yang dibuat Shopee adalah melalui penggunaan media atau secara langsung. Push strategy digunakan agar calon pengguna menjadi tahu akan Shopee. Push strategy dilakukan dengan cara membuat publikasi terkait program Shopee ke dalam media. Selain itu Shopee juga membuat suatu acara atau event.

Pull strategy berguna untuk pengguna mendatangi Shopee. Pull strategy yang digunakan berupa promosi penjualan berupa potongan harga atau gratis ongkir kepada calon pengguna Shopee. Pull strategy digunakan agar calon pengguna tertarik untuk memakai Shopee setelah melihat program Shopee yang ada.

Strategi yang dilakukan Shopee adalah untuk memberikan stimulan kepada calon pengguna dari segi kognitif, afektif dan konatif. Upaya pembentukan kesadaran merek Shopee secara kognitif adalah dengan membuat iklan dan program untuk memberikan pengetahuan tentang merek Shopee sehingga masyarakat Indonesia tahu bahwa Shopee merupakan e-commerce sebagai tempat belanja online.

Untuk membuat masyarakat tahu akan merek Shopee, Shopee membuat program dan promosi yang berkaitan dengan tren dan budaya di Indonesia. Di Indonesia, terdapat beberapa konten promosi, campaign dan program yang dibuat dengan berkaitan dengan Indonesia seperti adanya unsur dangdut, artis yang terkenal di Indonesia dan antusiasme masyarakat Indonesia akan cabang olahraga sepak bola.

Shopee menembus ke semua segmentasi, namun Shopee memiliki target khusus yaitu wanita. Alasan Shopee memilih gender wanita sebagai target utama karena wanita suka belanja baik secara online dan offline. Produk yang lebih banyak dibeli oleh pengguna beragam mulai dari produk kecantikan seperti alat dandan, pakaian, skincare, lotion, barang dari luar negeri dan lain-lain. Produk dibeli karena merupakan produk yang jarang ada di Indonesia.

\section{Tactics}

Taktik merupakan kumpulan detil strategi yang akan dilakukan. Taktik akan dituang dalam bauran pemasaran. Bauran komunikasi pemasaran yang digunakan Shopee adalah berupa pendekatan langsung melalui acara (event), periklanan, promosi penjualan, dan penjualan personal.

Shopee merupakan e-commerce yang dapat diakses hanya melalui online. Semua fitur yang terdapat pada Shopee dapat diakses secara online melalui situs web atau mengunduh aplikasi Shopee di perangkat seluler Iphone (App Store) dan Android (Google Play).

Adanya penambahan fitur-fitur yang unik adalah untuk menarik calon pengguna aplikasi Shopee. Fitur lain yang terdapat pada Shopee antara lain Goyang Shopee, Shopee Tangkap, Shopee Lempar, Shopee Tanam, dan ShopeePay. 


\section{Action}

Actions merupakan pengimplementasian strategi dan taktik ke dalam bentuk nyata. Bauran komunikasi pemasaran yang digunakan Shopee adalah berupa iklan, pendekatan langsung, penjualan personal dan promosi penjualan.

Penggunaan iklan yang singkat, padat dan selalu update. Iklan seperti "Shopee pee pee pee" secara pengulangan membuat pengguna mudah untuk mengingat. Penyebaran iklan menggunakan segala media secara online dengan menggunakan youtube dan media sosial. Sedangkan untuk penyebaran iklan secara offline dengan cara pemasangan papan billboard. Promosi penjualan yang dilakukan Shopee adalah berupa potongan harga dan gratis ongkir yang sekaligus menjadi salah satu keunggulan Shopee.

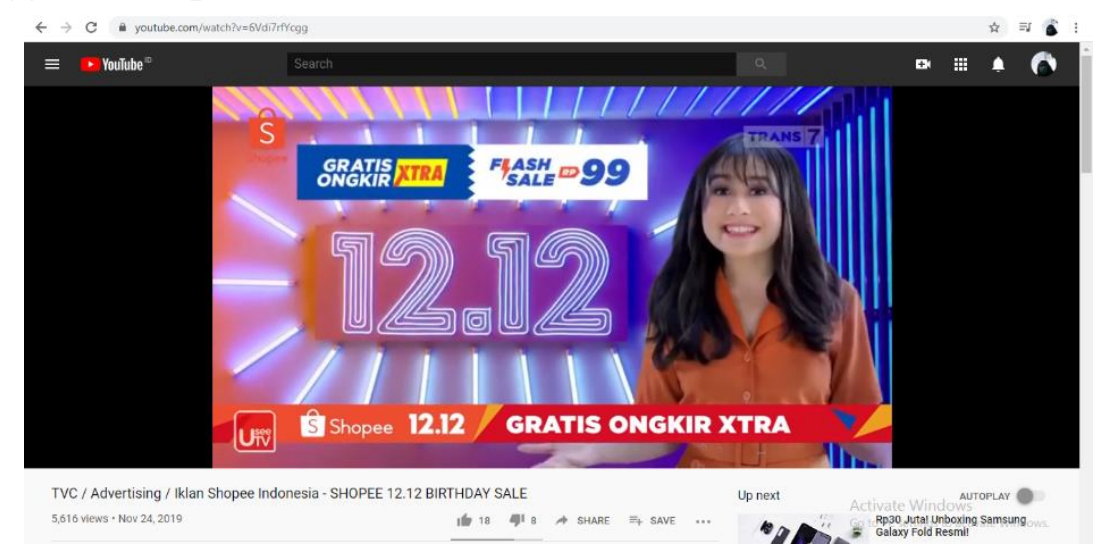

Penjualan langsung atau direct marketing yang dilakukan oleh Shopee adalah melalui acara off air dan acara televisi. Business Development Shopee, Yoga Pratama menjelaskan bahwa Shopee melakukan promosi langsung ke lapangan seperti mengadakan booth pada bazaar di acara off air, serta berpartisipasi dalam job fair. Alasan Shopee tetap memakai direct marketing adalah untuk menjaga keberadaannya di media sosial dan langsung. Kegiatan tersebut berguna agar memberikan kesadaran merek atau brand awareness atas merek Shopee kepada seluruh masyarakat dan pengguna.

Personal selling yang dilaksanakan adalah dengan melakukan rekomendasi dari online shop yang memiliki lapak di Shopee ke pengguna untuk melakukan transaksi melalui aplikasi Shopee. Shopee menggunakan personal image berupa brand ambassador. Tujuan Shopee memilih brand ambassador adalah untuk bisa semakin dekat dengan pengguna dan memperkuat posisi Shopee sebagai destinasi belanja online pilihan masyarakat Indonesia.

Tokoh brand ambassador juga dipilih bedasarkan apa yang sedang menjadi perhatian masyarakat, suatu momen yang sedang tren, dan dari apa yang menjadi minat dan kesukaan masyarakat. Salah satu contoh, adanya momen viral penyanyi dangdut, Via Vallen yang dipilih sebagai brand ambassador lokal di Indonesia.

Selain itu, pemain sepak bola, Cristiano Ronaldo sebagai official brand ambassador untuk Shopee secara internasional karena antusiasme akan sepak bola yang tinggi khususnya di Asia Tenggara. 


\section{Control}

Evaluasi yang dilakukan oleh Shopee berupa weekly meeting dan evaluasi tahunan. Pada weekly meeting diadakan evaluasi dengan cara mengadakan rapat membahas untuk suatu program seperti mengevaluasi perkembangan untuk campaign "11.11". Shopee juga mengadakan evaluasi tahunan yang membahas mulai dari pengembangan dan inovasi fitur ke depannya agar pengguna tidak bosan, dan membahas perbandingan antara suatu program antara tahun ini dengan tahun sebelumnya.

\section{Simpulan}

Bedasarkan hasil penelitian yang telah dilakukan oleh penulis tentang analisis strategi komunikasi pemasaran Shopee dalam persaingan e-commerce di Indonesia, dapat ditarik kesimpulan sebagai berikut.

Strategi komunikasi pemasaran Shopee adalah dengan menggunakan push and pull strategy. Push strategy yang digunakan adalah strategi promosi yang menggunakan bauran komunikasi pemasaran dan menggunakan program-program seperti iklan dan campaign. Hal ini bertujuan agar calon pengguna sehingga tahu dan terdorong untuk menggunakan Shopee. Pull strategy agar calon pengguna mendatangi merek. Bauran komunikasi pemasaran yang digunakan berupa promosi penjualan. Shopee pertama kali hadir dengan berbagai macam promo, salah satunya gratis ongkir. Hal tersebut membuat calon pengguna tertarik dalam menggunakan Shopee.

Untuk mengomunikasikan strategi yang disusun ke calon pengguna, Shopee menggunakan bauran komunikasi pemasaran berupa iklan, pendekatan langsung, pendekatan personal dan promosi penjualan. Iklan dengan karakter sederhana, padat dan pegulangan membuat konsumen tahu akan Shopee. Promosi penjualan (sales promotion) berupa promo gratis ongkir juga menjadi salah satu alasan konsumen tertarik menggunakan Shopee.

\section{Ucapan Terima Kasih}

Penulis mengucapkan terima kasih kepada kedua orang tua yang selalu mendukung, seluruh narasumber yang telah terlibat serta meluangkan waktu dalam penelitian ini serta kerabat penulis yang selalu memberikan dukungan kepada penulis selama penelitian.

\section{Daftar Pustaka}

CNN Indonesia. (2019, Mei 31). November 22, 2019. Indonesia Kuasai Duapertiga Total Transaksi Shopee. CNN Indonesia. https://www.cnnindonesia.com/teknologi/20190531063221-185399896/indonesia-kuasai-duapertiga-total-transaksi-shopee

CNN Indonesia. (2017, Agustus 11). November 22, 2019. Raja E-Commerce Indonesia; Lazada, Blibli.com, Bukalapak, Tokopedia atau Elevania. Youtube CNN Indonesia. https://www.youtube.com/watch?v=qWC_bjXmaUs 
Elissa, Ingge dan Mujiyana. (2013). Analisis Faktor-Faktor yang Mempengaruhi Keputusan Pembelian Via Internet pada Toko Online. Universitas Diponegoro Semarang. Jurnal Ekonomi Manajemen.

Priansa, Donni Juni. (2017). Komunikasi Pemasaran Terpadu Pada Masa Era Media Sosial. Bandung: Pustaka Setia.

Shopee Indonesia. (n.a). November 24, 2019. https://careers.shopee.co.id/about/ Sugiyono. (2016). Metode Penelitian Kuantitatif, Kualitatif, dan Kombinasi (Mixed Methods). Cetakan ke-8. Bandung: Alfabeta.

Suwatno. (2017). Komunikasi Pemasaran Konstektual. Bandung: Remaja Rosdakarya. 